\title{
Tandur Berkemas In Learning Mathematics
}

\author{
Winarno ${ }^{1}$, Hendri Handoko ${ }^{2 *}$ \\ ${ }^{1}$ SMAN 1 Tanjung 1, Jawa Tengah \\ ${ }_{2}^{2}$ Program Studi Pendidikan Matematika IAIN Syekh Nurjati Cirebon Jawa Barat. \\ *Corresponding author: hendrihandoko.iain.crb@gmail.com
}

\section{a r t i c l ein fo \\ How to cite this article: \\ Winarno \& Handoko, H. (2020). Bed Packaging In Learning Mathematics. Eduma : Mathematics Education Learning And Teaching, 9(1), 74 - 87. doi:http://dx.doi.org/10.24235/eduma.v9i1.5612}

Article history:

Received: 12 06, 2019

Accepted: 03 05, 2020

Published: 07, 2020

\section{$\operatorname{abstract}$}

TANDUR BERKEMAS IN LEARNING MATHEMATICS. Research objectives for increasing (1) independence; (2) problem solving skills; and (3) students' problem solving abilities in learning mathematics through the TandurBerkemas model of three dimensional material. The results showed an increase in all three aspects of learning outcomes, namely independence, skills, and student learning achievement. Independence increased from $58.82 \%$ to $100 \%$, skills $47.06 \%$ to $100 \%$, and learning achievement $64.71 \%$ to $97.06 \%$.
Keywords :

Tandur berkemas, independence, learning skills and achievement

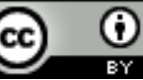

Open Access 


\section{INTRODUCTION}

One of the subjects given in accordance with the 2013 curriculum is mathematics. Learning mathematics in addition to requiring accuracy and tenacity, the other most important element that should not be forgotten is the spirit of learning more and never give up hope in learning it to grow an independent character in the soul of students.

Learning mathematics requires maximum concentration, because if it is not concentrated and does not understand from the beginning it will be wrong in determining the mathematical concept .. In this condition the teacher must be clever and creative in learning the basic concepts, while students themselves are required to be critical and creative so they can understand well when receiving new knowledge.Three dimensional learning is one of the materials that requires the imagination of students to be able to display abstract things to be more realistic. As stated by (Sumliyah, 2019)learning three dimensional material requires students to be able to think spatially imaginatively. So the teacher's task in this case must be able to create a lively atmosphere or an effective learning process to motivate students during the learning process. While (Lestari, D. Munawaroh,M \& Handoko, 2019)revealed that the task of the teacher should be able to connect the material provided in the classroom with everyday life so that the mindset is built on students that the material learned turns out to be an inseparable part of real life

Mathematics learning at this time still does not show a conducive learning process, this can be seen from the presence of various problems that cause the purpose of learning does not work as expected. Problems that often arise in learning mathematics can be identified as follows: (1) Student independence in the process of learning mathematics is still minimal, (2) Students 'skills in solving mathematical problems are still low, (3) The average value of students' mathematics learning achievement is still below $\mathrm{KKM}=70$ (not yet classically complete), and (4) The teacher in delivering material is still conventional (more dominant teacher learning) in classroom learning activities.Another thing stated by (Khodijah, Sahrodi, Handoko, \& Matematika, 2018) is that students have difficulty in working on problems that are different from the example problems given by the teacher. This condition is allegedly because when learning students only memorize formulas without coupled with a good understanding of concepts.

Data presented by (Toheri et al., 2017)states that $60 \%$ of high school mathematics teachers in Brebes Regency use learning media from books while the remaining $40 \%$ use laptops and projectors. This shows that in learning the teacher is still dominant in teaching material using books, the teacher is also less innovative in applying the learning model. So that learning in class looks monotonous, oneway and active student involvement in exploring their abilities is less so that it affects student learning outcomes

This can be shown from the results of the initial survey conducted by the author, namely from the average daily math test scores of students of class XII.MIPA.4 of 66.76. This figure does not meet the value of the complete limit or minimum completeness criteria for the specified mathematics subjects, namely KKM $=70$. 
The data was also strengthened by the classical completeness of students who only reached $47.06 \%$. Only 12 students out of 34 students in class XII.MIPA.4. Learning outcomes obtained from preliminary data can be shown in Figure 1, below.

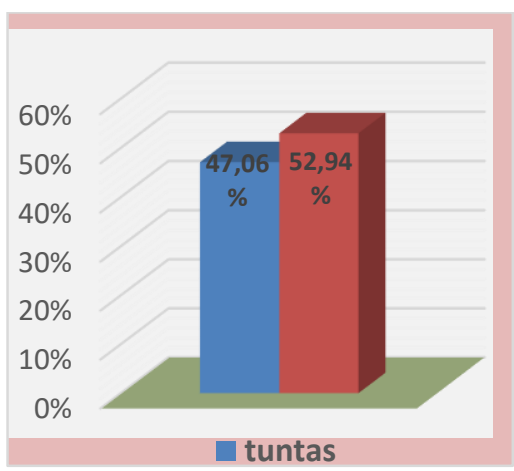

Figure 1 Learning Achievement of Student Initial Conditions

The diagram above shows the inequality in the acquisition of student achievement. Students who have not yet completed their studies more than students who have finished studying with a KKM limit of 70 in this study. This problem should be addressed immediately so that the results that are not optimal can be resolved immediately. One effort to improve the process of learning mathematics and to improve student learning outcomes, namely by using the Quantum Teaching model based on independent characters.

According to Sumahamijaya (Sumliyah, 2017) independent indicators include; initiative (prakasa), creativity (creativity), innovation (new inventions), improvisation (development / improvement) and pro-active

This model is able to meet the learning needs and enhance the active role of students in learning mathematics. The learning scenario follows the concept of the Quantum Teaching model, which uses the TANDUR syntax which consists of
Grow, Natural, Name, Demonstrate, Repeat, and Celebrate (DePorter, 2010) Through the application of the Quantum Teaching model based on independent characters in mathematics learning (Packaging Standards), it is expected that the activeness and independence of student learning will be higher, understanding of concepts will increase and can improve student learning outcomes.

In learning mathematics, appropriate strategies and learning models are needed in order to create a pleasant and meaningful learning atmosphere. Because basically according to (Handoko, 2017)mathematics other than as a master of scienceknowledge is also a tool, guiding mindsets and forming human attitudes

The Quantum teaching model is a learning model that prioritizes the optimization of students' abilities with the basic principle of being "bring their world to our world, and deliver their world". Students are not used as learning objects but are subject to learning, ie students are invited to be active or as a source of learning and a place to ask questions for their partners. The learning scenario follows the concept of the Quantum Teaching model, which uses the TANDUR syntax which consists of Grow, Natural, Name, Demonstrate, Repeat, and Celebrate (DePorter, 2010)

Based on the background and problem approach above, the purpose of writing this scientific paper is to develop a Quantum Teaching learning model with the TANDUR syntax combined with the application of independent characterbased learning, the Tandur Packing model. This Packaged Tandur Model is expected to increase student independence, students' learning skills 
and achievement in learning mathematics.

The benefits of this study are expected to be able to contribute to scientific understanding of the application of the Packaging Standards in improving student learning outcomes. This research is expected to be a material for comparison, consideration, and development for future research in the field and similar or related problems. For teachers, it can be used as insight and new learning alternatives in improving learning outcomes, especially in mathematics learning. For students, can provide motivation and new experiences in learning mathematics, especially in learning Three Dimensional material in a fun way, so as to improve student learning outcomes. For schools, this research can be used as a reference in improving learning outcomes and can be used as a guideline for principals to always motivate and help teachers to innovate in learning mathematics. For researchers, provide experience in writing and making improvements to learning that can be used as guidelines in future research.

\section{LITERATURE REVIEW THEORETICAL FRAMEWORKS}

Revealed that the principles in quantum teaching, namely (1) everything speaks, (2) everything aims, (3) experience before naming, (4) experience every effort, and (5) if worth learning it is also worth celebrating (DePorter, 2010).

Table 1

Learning Syntax of the Application of Quantum Teaching Model.
One of the formulations applied in the Quantum Teaching model is TANDUR, which is Grow, Natural, Name, Demonstrate, Repeat, and Celebrate (DePorter, 2010). In the implementation of teaching and learning in school models with six step concepts known as the TANDUR can be modified to: 1) Grow, meaning the teacher must try to foster interest and enthusiasm in student learning from the beginning to the end of learning; 2) Natural, means the teacher creates experiences that students can understand and understand; 3) Name, means the teacher provides keywords, models, rules, strategies, concepts or formulas that are used as input for students; 4) Demonstrate, means the teacher gives the opportunity for students to apply knowledge, link and demonstrate and practice that they understand the lesson / know; 5) Repeat, means the teacher motivates and directs students to repeat or reflect completion / learning to solidify understanding, concepts, or take notes on material summaries; and 6) Celebrate, meaning that the teacher gives appreciation, respect, appreciation or recognition to students for participation, completion, acquisition of skills and knowledge (Wena, 2017) explains the context categories of the quantum teaching model in the table as follows:

\footnotetext{
Context Model

Implementation in PBM

This relates to the arrangement of classrooms such as the

Environment arrangement of the learning chair tables, lighting, structuring learning media, pictures / posters on the classroom walls, plants in the classroom, structuring teaching aids (audiovisual media). Everything in the classroom must be arranged in such a way as to be
} 
Condition

Plane able to foster and stimulate a pleasant and conducive learning atmosphere.

This is related to the creation of students' inner mood while learning. A pleasant classroom physical environment may not necessarily foster and stimulate a pleasant and conducive learning atmosphere. Therefore, a teacher must be able to create a pleasant classroom atmosphere.

It is a framework that must be developed and agreed upon between teachers and students. This foundation includes (1) the same goals, (2) the same principles and values, (3) strong beliefs about learning and teaching, and (4) agreement, policy procedures and clear rules.

Students are given guidance and direction when discussing in groups. Students who become tutors are directed to guide friends in their groups.

Students are given the opportunity to demonstrate their ability to solve problems in group discussions and class presentations.
By paying attention to the principles and applying the eight keys to the excellence of Quantum Teaching in the learning design, the expected learning goals can be achieved, so that students' mathematics learning outcomes can be improved.

\section{Mathematics Learning Model Packaging Pack}

Mathematical learning through Packaged Tandur is learning that trains students to apply the concept of TANDUR, namely Grow, Natural, Name, Demonstrate, Repeat, and Celebrate (DePorter, 2010)From this formula we can draw an analogy that learning Quantum Teaching model means learning that consists of $6 \mathrm{M}$, which fosters enthusiasm for learning, experiences learning conditions, names activities or instills learning concepts, demonstrates completion in the learning process, repeats or reflects the results of completion in learning, and celebrating the success or learning outcomes gained in learning carried out both inside the classroom and outside the classroom.

The learning steps in the Quantum Teaching model are combined with the characters to be applied. In this study the character set to be achieved by students is the character of independence. (Sumahamijaya, 2003) suggest that independence is very much needed, in this case it cannot be realized without going through a process of education and training. (Elfindri dkk, 2012)emphasized the independent character as an attitude and behavior that is not easily dependent on others in completing certain tasks.

According to (Syahputra, 2017) students who have learning independence have the ability to solve complex problems. In addition to being responsive in person, they are also able to work with other people or groups and have the courage to convey ideas

From the above understanding, it can be concluded that the Packaging Tandur model as an innovation learning that combines the learning steps of the Quantum Teaching model with the character of independence. The syntax of learning mathematics with the Packaging Standards model that can improve 
mathematics learning outcomes can be shown in Table 2, as follows.

Tabel 2

SintaksLearning of Tandur Berkemas

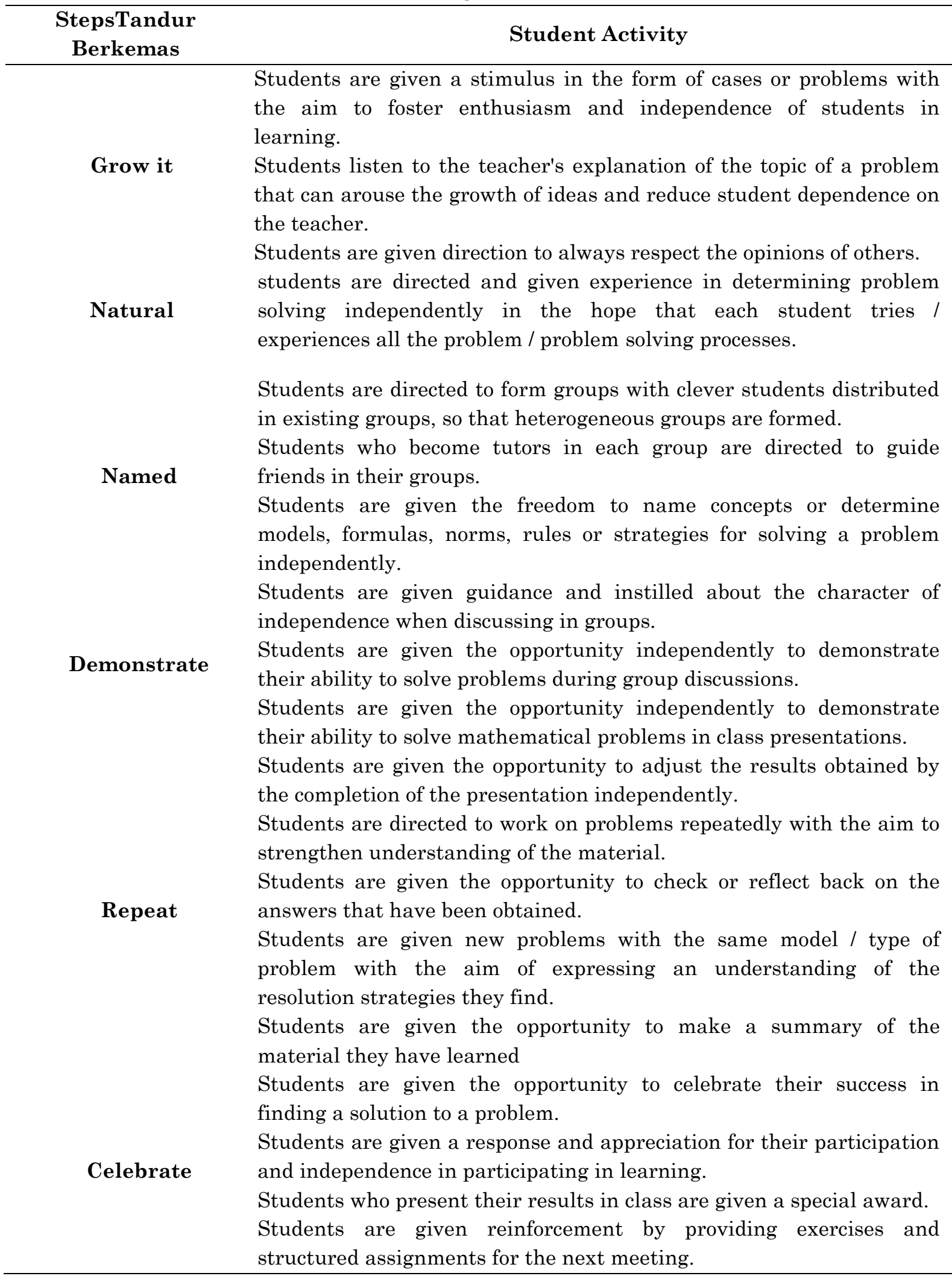


the packaging packing principle. As for the activities carried out, as follows: 1) Identification of problems found in the initial conditions; 2) Arrange a schedule of learning implementation activities; 3) Develop learning instruments 4) Gather learning resources, learning media, teaching aids (if needed), and other supporting materials; 5) Make a scenario for the implementation of the packaging package and 6) Make a plan of action, namely: the teacher directs students to increase their independence in discussion (guiding each other), the teacher gives direction / guidance to students to be more active, enthusiastic, and independent in discussion, forming groups heterogeneous, complete media / props that are more varied, stimulate students to dare to express opinions, give direction to students to make conclusions independently, and provide structured assignments as follow-up material for further meetings.

Tandur learning scenario Packs by applying Quantum Teaching learning based on independent characters. The learning steps can be seen in Table 3 , as follows.

Table 3

Scenario Packaging Learning Scenarios

Timing $\begin{aligned} & \text { Steps for packing the tandur berkemas } \\ & \text { Student Activities }\end{aligned}$
Preliminary
1. Students prepare themselves psychologically and physically by
answering greetings from the teacher.
2. Students pay attention to information about competencies, the scope of
the material, objectives, benefits, and scenarios and learning models /
techniques that will be implemented.
Core activities
Step T: Grow
The teacher provides stimulus in the form of cases or problems with
the aim to foster student enthusiasm in learning by choosing the
character of independence as a character that must be instilled.
The teacher explains the topic of a problem by explaining terms that
can arouse students' idea growth and grouping facts independently.
The teacher gives direction to students to appreciate and uphold the
value of the character of independence in exploring the problem.
Step A: Natural
The teacher guides and directs students in determining problem solving
in the hope that each student tries / experiences all the process of working
on the problem by applying the character of independence in planning the
solution.
Step N: Named
The teacher forms and gives the name of the group to facilitate the
observation and management of learning when students discuss planning
for completion independently.
The teacher appoints a tutor from each group drawn from the students


who stand out in the group.

The teacher gives freedom to students so that they can independently

determine models, formulas, norms, rules or strategies in solving a

problem without being dependent on others.

\section{METHODS}

The research subjects were students of SMA 1 Tanjung class XII.MIPA.5 in semester 2 of the 2015/2016 academic year, totaling 34 students, 12 males and 22 females. This research was conducted at SMA Negeri 1 Tanjung in Brebes Regency. The study was conducted in 3 months, namely January to March 2016. The variables studied were activity, independence, skills, and learning achievement of students of class XII.MIPA.5 SMA Negeri 1 Tanjung in the academic year 2015/2016. Data collection using test and non-test techniques. The test technique uses test questions related to integral material, while the non-test technique is observation, document review, assignment and journal. Data were analyzed using comparative descriptive analysis, which is an analysis by comparing the values in each cycle. Student test results are an indicator of the success of this class action research. In detail, the benchmarks of success are if individual student learning outcomes reach $70 \%$ and classically $85 \%$. That is, classroom success can be seen if the number of students who achieve learning outcomes $70 \%$ is at least $85 \%$ of the total number of students XII.MIPA.5.

Stages of activities carried out in the study, namely: (1) planning, implementation, (3) observation, and (4) reflection. The planning phase of cycle 1 in this study includes (1) identification of problems encountered in pre-cycle actions, (2) preparing a cycle 1 learning plan, and (3) preparing research instruments that will be used in cycle 1 activities, especially the observation instruments of process activities learning on the aspects of independence and student skills and learning achievement test instruments. The implementation phase, the researcher carried out learning activities with the Quantum Teaching model by determining the group and the group leader as a guide or tutor in the discussion activities were the most prominent students in the group. The grouping of student discussions in this stage tends to be homogeneous. The material provided is an integral application in determining the area of the curve. This activity was realized in two meetings namely on Thursday and Saturday, 18 and 20 February 2016.

The observation phase is carried out for taking initial research data. The data taken in the study are data on progress or student learning outcomes which include (1) aspects of attitude, namely by observing the character of student independence; (2) aspects of skills, using students' observation skills; and (3) aspects of knowledge by using evaluation in the form of learning achievement tests to measure students' intellectuals in cycle 1 of learning by using the Quantum Teaching model on material derived from trigonometric functions.

At the reflection stage the data obtained at the observation stage are analyzed. This reflection activity is carried out with two techniques, namely analyzing quantitative data in the form of daily test scores or cycle 1 tests as a result of student learning achievement. Students' mastery learning can be seen from the scores obtained on the test, both for classical and individual completeness. 
And analyzing qualitative data in the form of data obtained from observations while learning takes place during the initial research. This data includes two assessments of learning outcomes, namely the assessment of aspects of attitude in the form of observing the character of students 'independence in learning and aspects of skills by observing students' skills in solving problems at the implementation stage. This data is processed using the conversion value of tens of 100-100. As well as identifying weaknesses in the initial research implementation stage to determine the planning steps in the advanced research stage.

Stages of activities carried out in further research with the steps of the same activity with the initial research. At this stage the researchers carried out the planning stage starting with identifying the problems found in cycle 1, compiling a learning plan for action cycle 2 with a character-based Quantum Teaching model on the material derived from trigonometric functions with heterogeneous group divisions and tutors drawn from smart students in his group as a guide to the progress of other students who are in the category of low ability, prepare a research instrument that will be used in conducting further research, which includes an attitude observation instrument in the form of student independence character, an instrument of observing student skills, and an achievement test instrument for further research.

At this stage the researchers carried out learning activities by applying the Quantum Teaching model based on independence character. Grouping students in a heterogeneous discussion setting, means that in group discussions the distribution of students is made evenly, which consists of smart, mediumcapable, or low-ability students. The material provided in this activity step is an integral application in determining the volume of a rotating object. This stage was carried out in two meetings namely, 25 and 27 February 2016. The researcher motivated students in mastering the subject matter discussed. This activity is carried out with a learning atmosphere that is designed communicative and fun so that students are able to explore abilities in group discussion activities and classically presentations in class.

The Observation Phase is a stage of further research data collection. The data in question is distinguished in quantitative and qualitative data. Quantitative data are in the form of evaluation scores taken from achievement tests in advanced research and qualitative data in the form of data obtained from observations of the character of independence and observation of student skills. Qualitative data obtained from observations using indicators that have been prepared and packaged in the observation instrument regarding learning outcomes on aspects of student attitudes and skills. The data is analyzed to determine the effectiveness of actions in further research. If the action taken is effective it will be seen an increase in student learning outcomes at this stage.

The advanced research phase is used to analyze the completeness of learning outcomes for qualitative and quantitative data obtained from observations and learning achievement test scores. The success of this study if the learning outcomes of students in class XII.MIPA.5 has reached $85 \%$ of the total number of students who achieved a score of $\geq 70$ or completed learning. 


\section{RESULT AND DISCUSSION}

The results of observing the character of students' independence in learning can be shown in Table 4, below.

Table 4

Character of Student Independence in Learning

\begin{tabular}{llccc}
\hline Criteria & Score & F & $\%$ & Note \\
& & & & \\
\hline $\begin{array}{l}\text { Very } \\
\text { good }\end{array}$ & $N \geq 86$ & 7 & $20,59 \%$ & \\
Well & $\begin{array}{l}70 \leq N \\
\leq 85\end{array}$ & 27 & $79,41 \%$ & \\
& & & \\
Enough & $\begin{array}{l}54 \leq N \\
\leq 69\end{array}$ & 0 & $0 \%$ & \\
& & & & Lossed \\
Not good & $N \leq 53$ & 0 & $0 \%$ & \\
\hline
\end{tabular}

The results of observing the character of students' independence in learning shown in Table 4 taken from observations on learning can be explained, as follows: 1) Students who get the value of independence with very good criteria 7 children (20.59\%); 2) Students who get independence by good criteria 27 children (79.41\%); 3) Students who get the value of independence with sufficient criteria does not exist; 4) Students who get the value of independence with unfavorable criteria no.

From the above explanation it can be concluded that the learning package packing of 34 students in achieving the value of independence or complete learning aspects of the attitude of 34 children or completeness reaches 100\%. This means that learning meets the indicators of student independence success in learning has been reached or exceeds $85 \%$.

As for the results of observations of student skills in the packaging tandur berkemas, it can be shown in Table 5, below.

Table 5

Recapitulation of Student Skills in Packaging Packaging Principles

\begin{tabular}{|c|c|c|c|c|}
\hline Criteria & Score & $\mathbf{F}$ & $\%$ & Note \\
\hline $\begin{array}{l}\text { Very } \\
\text { good }\end{array}$ & $N \geq 86$ & 4 & $11,76 \%$ & \\
\hline Well & $\begin{array}{l}70 \leq N \\
\leq 85\end{array}$ & 30 & $88,24 \%$ & Passed \\
\hline Enough & $\begin{array}{l}54 \leq N \\
\leq 69\end{array}$ & 0 & $0 \%$ & Lossed \\
\hline Not good & $N \leq 53$ & 0 & $0 \%$ & \\
\hline
\end{tabular}

The results of observations of student skills in learning in Table 5 taken from observations on learning can be explained, as follows: 1) Students who score skills with very good criteria are 4 children (11.76\%); 2) Students who get skills with good criteria of 30 children (88.24\%); 3) Students who get skill scores with sufficient criteria are absent and 4) Students who get skill scores with unfavorable criteria are absent.

The explanation above shows that in the tandur berkemasgage learning act, students' skills experience a significant increase. Students who have reached completion of learning in the assessment of aspects of skills (in very good and good criteria) to 34 students or all students in class XII.MIPA.5 achieve completion of learning. This means that indicators of success in assessing learning outcomes of aspects of student skills have also been fulfilled.

Student learning achievement in the packaging packaging can show significant improvement. Data on student achievement on taken from the test scores are shown in Table 6 , below. 
Table 6

Recapitulation of Student Learning Achievement in Learning

\begin{tabular}{|c|c|c|c|c|}
\hline Criteria & Score & $\mathbf{F}$ & $\%$ & Note \\
\hline $\begin{array}{l}\text { Very } \\
\text { good }\end{array}$ & $N \geq 86$ & 4 & $11,76 \%$ & \multirow[b]{2}{*}{ Passed } \\
\hline Well & $\begin{array}{l}70 \leq N \\
\leq 85\end{array}$ & 30 & $88,24 \%$ & \\
\hline Enough & $\begin{array}{l}54 \leq N \\
\leq 69\end{array}$ & 0 & $0 \%$ & \multirow[t]{2}{*}{ Lossed } \\
\hline Not good & $N \leq 53$ & 0 & $0 \%$ & \\
\hline
\end{tabular}

Based on the recapitulation of student achievement in further research summarized in Table 6, 33 students who have finished learning with KKM = 70 (15 students with very good grades and 18 children with good grades) or mastery learning reach $97.06 \%$. While students who have not yet completed study are 1 child with a predicate of sufficient criteria or incompleteness of $2.94 \%$.

By paying attention to Table 6, the students' learning achievement in the Packaging Tandur can be described, as follows: 1) students who get excellent learning achievement scores of 86-100, namely 15 children (44.12\%); 2) students who get a good learning achievement score between $70-85$, namely 18 children (52.94\%); 3) students who get a learning achievement score with a predicate of between 54-69, namely 1 child (2.94\%); and 4) students who score poorly between 0-53, no.

The results of completeness student achievement can be shown in Figure 2, below.

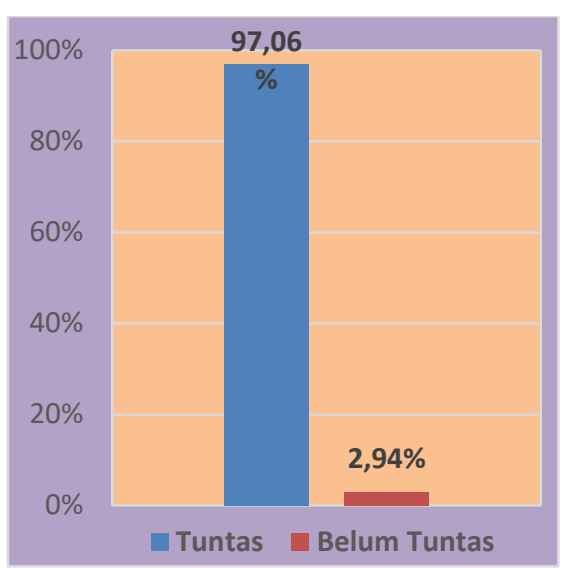

Figure 2. Student Learning Achievement

Figure 2 shows that the results of the learning achievement test in the Packaging Tandur have reached the goal or exceeded the target, namely classical completeness of $97.06 \%$ or 33 children out of 34 students in the class have received a complete grade of learning.

\section{CONCLUSION AND IMPLICATION}

\section{a. Conclusion}

Based on the results and discussion in this study, it can be concluded that: 1) Packaged Tandur Learning can improve learning outcomes of aspects of attitudes, skills, and knowledge of students in learning mathematics to calculate the distance of the three dimensions. Learning outcomes show an increase with classical completeness of $85 \%$; 2) The character of student independence increases after applying Packaging Standards in learning mathematics material to calculate distance of Three Dimensions; 3) Students' skills in solving problems increased after applying the Quantum Teaching model based on the independence of character in learning mathematics material to calculate distance of Three Dimensions and 4) Student achievement also increased to $97.06 \%$. These results indicate that students' learning achievement in 
mathematics learning of Dimension Three with the application of the Quantum Teaching model based on independence character achieves classical completeness $85 \%$.

\section{b. Implication}

The application of the Tandur Packing model should be used as a medium or a means for students to practice, recognize each other's attitudes, guide, develop skills, familiarize critical and creative thinking in solving mathematical problems, so as to be able to work innovatively in everyday life. Learning Tandur models Packing on Integral material provides insights and alternative learning strategies that can be applied by teachers in efforts to improve teaching abilities. Research using the Packing Tandur model can be used as a reference in the development of learning innovations as an effort to improve the quality and quality of education and school performance.

\section{REFERENCES}

DePorter, B., Reardon, M., \& Singer-Nourie, S. (2010). Quantum teaching: mempraktikkan quantum learning di ruang-ruang kelas. Kaifa.

Elfindri, L. H., Wello, M. B., Hendmaidi, E. E., \& Indra, R. (2012). Pendidikan Karakter Kerangka, Metode dan Aplikasi Untuk Pendidikan dan Profesional. Jakarta: Baduose Media Jakarta.

Handoko, H. (2017). Pembentukan Keterampilan Berpikir Kreatif Pada Pembelajaran Matematika Model Savi Berbasis Discovery Strategy Materi Dimensi Tiga Kelas X. Eduma: Mathematics Education Learning and Teaching, 6(1), 85-95. http://dx.doi.org/10.24235/eduma.v6i $\underline{1.1711}$

Khodijah, I., Sahrodi, J., \& Handoko, H. (2018). Penerapan Model Paikem Melalui Pendekatan Index Card Match untuk Meningkatkan Kemampuan Pemecahan Masalah Matematika Siswa. Integral: Pendidikan Matematika, 9(2), 25-36. https://doi.org/10.32534/jnr.v9i2.777

Lestari, D., Munawaroh, M., \& Handoko, H. (2019). Pengaruh Penerapan Model Pembelajaran Bamboo Dancing Berbantuan Permainan Ular Tangga untuk Meningkatkan Hasil Belajar Matematika Siswa. Integral: Pendidikan Matematika, 10(1), 2839.

https://doi.org/10.32534/jnr.v10i1.63 $\underline{8}$

Sumahamijaya, S., Yasben, D., \& Dana, D. A. (2003). Pendidikan karakter mandiri dan kewiraswastaan: suatu upaya bagi keberhasilan program pendidikan berbasis luas/broad based education dan life skills. Bandung: Angkasa Bandung.

Sumliyah, S. (2017). Efektivitas Pendekatan Value Clarification Technique Berbasis Karakter Kemandirian pada Keterampilan. EduMa, 6(1), 23-31. https://doi.org/10.24235/eduma.v6i $\underline{1.1560}$

Sumliyah, S. (2019). Penerapan Media Pembelajaran Cabri 3D pada Kemampuan Pemahaman Konsep Matematika SMK Materi Bangun Ruang. Integral: Pendidikan Matematika, 10(1), 16-27. https://doi.org/10.32534/jnr.v10i1.63 $\underline{7}$

Syahputra, D. (2017). Pengaruh Kemandirian Belajar dan Bimbingan Belajar terhadap Kemampuan Memahami Jurnal Penyesuaian pada 
Siswa SMA Melati Perbaungan. ATTAWASSUTH: Jurnal Ekonomi Islam, 2(2), 368-388. http://dx.doi.org/10.30821/ajei.v2i2.1 $\underline{227}$

Toheri, Hendri, R, \& Hendri, H. (2018). Perlu Tapi Tidak Pernah: Pengembangan Bahan Ajar Berbasis Geogebra. Retrieved from http://repository.syekhnurjati.ac.id/3 $\underline{119 /}$

Wena, M. (2009). Strategi pembelajaran inovatif kontemporer suatu tinjauan konseptual operasional. Jakarta: Bumi Aksara. 